\title{
PROBLEMATIKA VERIFIKASI DATA CALON PENGANTIN
}

\section{Hayaturrohman}

Prodi Pendidikan Agama Islam, Fakultas Agama Islam, Universitas Nahdlatul Ulama

Indonesia

E-mail: hayaturrohman@unusia.ac.id

\author{
Article Information \\ Informasi Artikel \\ Naskah diterima: 11 Juli \\ 2018 \\ Naskah direvisi: 28 \\ September \\ Naskah disetujui : 10 \\ September \\ Naskah dipublish: \\ Oktober 2018
}

Kata Kunci Pernikahan, Pembatalan Pernikahan, Verifiaksi Data

\begin{abstract}
Abstak
Tujuan perkawinan adalah untuk membentuk keluarga (rumah tangga) yang bahagia dan kekal berdasarkan Ketuhanan Yang Maha Esa. Perkawinan yang bahagia dalam kehidupan keluarga yang bahagia, Inilah cita-cita dan idaman bagi tiap-tiap manusia baik laki-laki maupun perempuan. Hanya saja kebahagiaan itu tidak bisa ditebak, kadang sering datang dan kadang sering pergi, kadang ketika kebahagiaan yang diharapkan, namun kadang juga ternyata kekecewaan yang datang.

Di dalam Peraturan Pemerintah No. 9 tahun 1975 (yang selanjutnya disebut PP) pasal 3 ayat (1) menjelaskan bahwa "setiap orang yang akan melangsungkan perkawinan memberitahukan kehendaknya itu kepada pegawai pencatat di tempat perkawinan akan dilangsungkan ${ }^{l}$. Hal ini menerangkan bahwa setiap orang yang ingin melangsungkan pernikahan harus melaporkan atau memberitahukan kehendaknya agar perkawinannya dicatatkan dan memiliki kekuatan hukum.
\end{abstract}

\section{PENDAHULUAN}

Tujuan perkawinan adalah untuk membentuk keluarga (rumah tangga) yang bahagia dan kekal berdasarkan Ketuhanan Yang Maha Esa. Perkawinan yang bahagia dalam kehidupan keluarga yang bahagia, Inilah cita-cita dan idaman bagi tiap-tiap manusia baik laki-laki maupun perempuan. Hanya saja kebahagiaan itu tidak bisa ditebak, kadang sering datang dan kadang sering pergi, kadang ketika kebahagiaan yang diharapkan, namun kadang juga ternyata kekecewaan yang datang.

Di dalam buku "Hukum Perkawinan Islam Dan Undang-Undang Perkawinan" yang ditulis Soemiyati. Ia menjelaskan sebagai berikut: "tujuan perkawinan dalam islam adalah untuk memenuhi tuntutan hajat tabiat kemanusiaan, hubungan antara laki-laki dan perempuan dalam rangka mewujudkan suatu keluarga yang bahagia

\footnotetext{
${ }^{1}$ K. Wantjik Saleh, Hukum Perkawinan Indonesia, h.74.
} 
dengan dasar cinta dan kasih sayang, untuk memperoleh keturunan-keturunan yang telah diatur oleh syari'ah"2.

Di samping itu, dengan ditetapkannya perkawinan, manusia dapat menurunkan generasi penerusnya. Dan ini berarti manusia dapat melestarikan kelangsungan hidup berikutnya dan kesinambungan keluarga dapat terjamin serta kebanggaan keluarga dapat diteruskan ${ }^{3}$. Pada dasarnya pernikahan itu berasaskan monogami, monogami menjadi salah satu asas akan tetapi terdapat pengecualian. Pengecualian itu diatur oleh UUP pasal 3 ayat 1 dan 2 yang berbunyi:

1. Pada asasnya dalam suatu perkawinan seorang pria hanya boleh mempunyai seorang istri dan seorang wanita hanya boleh mempunyai seorang suami.

2. Pengadilan dapat memberikan izin kepada seorang suami untuk beristri lebih dari seorang apabila dikehendaki oleh pihak-pihak yang bersangkutan.

Untuk terjaminnya pernikahan yang sejahtera dan bahagia, maka diperlukan perkawinan. Tidak ada kebahagiaan tanpa adanya perkawinan yang sah. Perkawinan dianggap sah adalah perkawinan yang dilaksanakan menurut masing-masing agama dan kepercayaannya, serta dicatat menurut peraturan perundang-undangan yang berlaku. Di Negara Indonesia ada dua instansi atau lembaga yang diberi tugas untuk mencatat perkawinan dan perceraian (dan ruju'). Adapun instansi atau lembaga yang dimaksud adalah:

1. Kantor Urusan Agama Kecamatan untuk Nikah. Talak, dan Ruju' bagi orang yang beragama Islam;

2. Kantor Catatan Sipil (Burgerlijk Stand) ${ }^{4}$.

Di dalam Peraturan Pemerintah No. 9 tahun 1975 (yang selanjutnya disebut PP) pasal 3 ayat (1) menjelaskan bahwa "setiap orang yang akan melangsungkan perkawinan memberitahukan kehendaknya itu kepada pegawai pencatat di tempat perkawinan akan dilangsungkan ${ }^{5}$. Hal ini menerangkan bahwa setiap orang yang ingin

\footnotetext{
${ }^{2}$ Soemiyati. Hukum Perkwinan Islam dan Undang-UndangPerkawinan. (Yogyakarta: Liberti,1997) h.12.

${ }^{3}$ Abdullah Nashih 'Ulwan, Tata Cara Meminang Dalam Islam, h. 6.

${ }^{4}$ Abdul Manan, Aneka Masalah Hukum Perdata Islam di Indonesia, (Jakarta: Kencana Prenada Media Group, 2006), h.1.

${ }^{5}$ K. Wantjik Saleh, Hukum Perkawinan Indonesia, h.74.
} 
melangsungkan pernikahan harus melaporkan atau memberitahukan kehendaknya agar perkawinannya dicatatkan dan memiliki kekuatan hukum.

Berdasarkan masalah di atas, maka hubungannya dengan sistem peradilan di Indonesia, perkawinannya dapat dibatalkan. Seperti yang dicantumkan dalam UUP pasal 22 yaitu: "Suatu perkawinan dapat dibatalkan apabila perkawinan tidak memenuhi syarat-syarat untuk melangsungkan perkawinan." Dan di dalam pasal 9 berbunyi: "Seorang yang terikat tali perkawinan dengan orang lain tidak dapat kawin lagi, kecuali dalam hal yang tersebut pada pasal 3 ayat 2 dan pasal 4 undang-undang ini".

Adapun pihak-pihak yang dapat mengajukan permohonan pembatalan seperti dicantumkan dalam Kompilasi Hukum Islam (yang selanjutnya disebut KHI) pasal 73 ayat 3 adalah: "Pejabat yang berwenang mengawasi pelaksanaan perkawinan menurut undang-undang"'6.

Perkawinan seperti ini pernah terjadi pembatalannya di Pengadilan Agama Depok dengan putusan Nomor 563/Pdt.G/2007/PA.Dpk, yaitu: seorang wanita bernama Aminah (Tergugat I) telah berpisah dengann suaminya bernama Yanto sekitar kurang lebih 1 tahun, kemudian Aminah menikah kembali dengan seorang laki-laki lain bernama Udin (Tergugat 2). pernikahan antara Aminah dan Udin dicatatkan di Kantor Urusan Agama Kecamatan Cimaggis Kota Depok pada tanggal 8 april 2006 dengan Akta Nikah No. 10/9/46/2006.

Akad nikah tersebut dilangsunglkan dihadapan Pegawai Pencatat Nikah KUA Cimaggis Kota Depok yang bernama Abdurrahman (Penggugat). Sebelum dilangsungkan pernikahan, kedua mempelai datang ke KUA Kecamatan Cimaggis Kota Depok untuk memberitahukan kehendaknya untuk menikah. Kemudian saudara Abdurrahman selaku penghulu KUA Kecamatan Cimaggis melakukan pemeriksaan, pengumuman kehendak nikah, akad nikah dan penandatanganan akta nikah sesuai ketentuan UU No. 22 Tahun 1946 jo. Pasal 6 s/d 13 UU No. 1 Tahun 1974 jo. Pasal 14 s/d 29 Kompilasi Hukum Islam. Berdasarkan hal itu, maka KUA Kecamata Cimanggis mengeluarkan Kutipan akta nikah. kendati demikian, setelah pernikahan itu telah berlangsung kurang lebih 1 tahun, dan Yanto mengetahui pernikahan itu ia pun

\footnotetext{
${ }^{6}$ Abdurrahman, Kompilasi Hukum Islam di Indonesia, (Jakarta: Akademika Pressindo, 2007), h.131.
} 
langsung melaporkan ke Kepolisian Sektor Cimanggis dengan modus Operandi (pelaku menikah tanpa sepengetahuan suami). Selanjutnya pihak kepolisian mengintrogasi saudari Aminah dan saudara Udin ditemukan fakta bahwa perkawinan mereka dinyataka cacat hukum karena saudari Aminah masih terikat dalam pernikahan dengan orang lain dan proses perceraiannya masih berjalan di Pengadialn Agama Depok.

Kemudian pihak kepolisian meminta agar saudara Abdurrahman selaku pegawai pencatat nikah yang berwenang menikahkan saudari Aminah dan saudara udin untuk mengajukan gugatan ke Pengadilan Agama Depok karena merupakan kewenangan Pengadilan Agama setempat. Gugatan ini diajukan bertujuan agar perkawinan saudara Aminah dengan saudara Udin dibatalkan.

\section{PEMBAHASAN}

Di dalam pelaksanaan pernikahan, pada dasarnya calon pengantin dituntut dengan berbagai macam persyaratan yang harus dipenuhi sebelum pernikahan itu dilaksanakan. Hal ini dilakukan agar dikemudian hari tidak terjadi hal-hal yang tidak dinginkan. Dalam pelaksanaan perkawinan harus mengikuti perosedur yang telah ditentukan yang mana suatu perkawinan harus diawasi dan dilakukan oleh pegawai Kantor Urusan Agama Kecamatan, petugas tersebut biasa disebut dengan Pegawai Pencatat Nikah (PPN). Hal ini seperti disebutkan dalam Undang-Undang No.22 tahun 1946 tentang Pencatatan, Nikah Talak dan Rujuk pasal ayat (1) dan (2) yaitu:

1. Nikah yang dilakukan menurut agama Islam, selanjutnya disebut nikah, diawasi oleh Pegawai Pencatat Nikah yang diangkat oleh Menteri Agama atau oleh pegawai yang ditunjuk olehnya. Talak dan Rujuk yang dilakukan menurut agama Islam selanjutnya disebut talak dan rujuk, diberitahukan oleh Pegawai Pencatat Nikah.

2. Yang berhak melakukan pengawasan atas nikah dan menerima pemberitahuan tentang talak dan rujuk, hanya pegawai yang diangkat oleh Menteri Agama atau oleh pegawai yang ditunjuk olehnya ${ }^{7}$.

Berdasarkan undang-undang tersebut, jika suatu perkawinan tidak melului prosedur yang ada atau tidak diawasi oleh PPN maka pernikahan tersebut tidaklah berkekuatan hukum, baik dalam hal status perkawinannya maupun ketika mereka telah

\footnotetext{
${ }^{7}$ Dirjen Bimas Islam, Pedoman Pegawai Pencatat Nikah PPN, h.208.
} 
memiliki keturunan, yang mana keturunannya dianggap tidak jelas karena tidak memiliki akta kelahiran atau surat kenal lahir. Hal ini disebabkan oleh pernikahan yang tidak memlalui prosedur yang ada, karena dalam pembuatan akta kelahiran diperlukan surat nikah yang mana untuk memperoleh surat nikah harus dengan suatu pernikahan yang sesuai dengan peraturan/ketentuan yang berlaku.

Adapun tugas dari PPN adalah memeriksa data-data apabila ada yang ingin melaksanakan perkawinan. Hal itu dilakukan setelah mendapat surat keterangan dari pihak Kelurahan/Kepala Desa kemudian setelah itu, pihak KUA memeriksa keadaan dari calon pengantin. Dalam hal pemeriksaan ini adalah mengenai status apakah masih jejaka/perawan atau duda/janda. Hal ini sebagai proses tata cara pencatatan sebagaimana yang telah disebutkan di atas.

Hal tersebut sudah diatur dalam peraturan perundang-undangan yaitu:

1) Undang-undang Nomor 1 tahun 1974 tentang Pernikahan;

2) Undang-Undang Nomor 32 tahun 1954 tentang Berlakunya Undang-undang RI Nomor 22 tahun 1946 tentang Pencatatan Nikah, Talak dan Rujuk di seluruh Daerah Luar Jawa dan Madura,

3) Undang-Undang Nomor 22 tahun 1946 tentang Nikah, Talak dan Rujuk;

4) Peraturan Pemerintah Nomor 9 tahun 1975 tentang Pelaksanaan Undang-Undang Nomor 1 tahun 1974 tentang Perkawinan;

5) Peratura Menteri Agama Nomor 3 tahun 1975 Tentang Kewajiban Pegawai Pencatat Nikah dan Tata Kerja Pengadilan Agama Dalam Melaksanakan Peraturan PerundangUndangan;

6) Surt Edaran Nomor DII/Ed/61/76 tanggal 26 Maret 1976 Tentang Pembukuan Blanko/Formulir Administrasi NTCR, dll.

Semua peraturan itu mengatur dan melakukan penelitian terhadap data calon pengantin yang dijadikan dasar atau pijakan dalam meneliti data calon pengantin. Karena dalam masalah pernikahan ketelitian itu sangat diperlukan agar dikemudian hari tidak terjadi hal-hal yang tidak diinginkan. Dan berdasarkan itulah tidak mungkin terdapat kesalahan atau kekeliruan.

Dalam hal kata mengawasi dapat memiliki arti yang luas yang terdiri dari beberapa arti, yaitu: 
1. Memeriksa dan meneliti calon suami, calon isteri dan wali nikah tentang halangan perkawinan dan syarata-syarat yang harus dipenuhi, baik menurut ketentuan hukum syara' (hukum munakahat) ataupun peraturan perundang-undangan yang berlaku.

2. Meneliti surat-surat yang harus dipenuhi oleh masing-masing yang bersangkutan;

3. Menghadiri dan menyaksikan upacara akad nikah ${ }^{8}$.

Dengan adanya proses tersebut seharusnya tidak dapat terjadi kesalahan ataupun kekeliruan (penyimpangan) yaitu pemalsuan identitas. Karena dalam setiap tahapan dari mulai mengajukan kehendak nikah sampai tahapan terakhir yaitu pencatatan perkawinan yang setiap tahapan itu masing-masing memiliki blanko, dengan kata lain tidak mungkin data-data yang telah diperiksa dan diteliti terdapat kesalahan atau kekeliruan.

Adapun jika ditemui kesalahan atau kekeliruan terhadap data calon pengantin, hal ini dapat dipicu oleh 2 (dua) faktor, yaitu:

\section{Faktor Intern}

Kurangnya ketelitian yang dilakukan oleh pihak KUA dalam memeriksa dan meneliti calon suami, calon isteri dan wali nikah tentang halangan perkawinan dan syarat-syarat yang harus dipenuhi, baik menurut ketentuan hukum syara' ataupun peraturan perundang-undangan yang berlaku dan data-data calon pengantin yang diberikan calon pengantin ketika mengajukan kehendak nikah

\section{Faktor Ekstern}

Sedangkan dari faktor ekstern, hal ini dapat disebabkan dari berbagai pihak, yaitu:

1. Para pihak yang ingin melaksanakan nikah yaitu para calon pengantin yang dengan sengaja memanipulasi data diri yang diajukan dan

diberikan keberbagai pihak seperti RT, RW, dan Kelurahan sebelum diberikan kepada pihak KUA.

2. Selain kesalahan dari pihak calon pengantin, hal ini juga dapat ditimbulkan dari pihak-pihak yang bersangkutan, misalnya dalam permasalahan status duda/janda yang

\footnotetext{
${ }^{8}$ Dirjen Bimas Islam , Himpunan Peraturan Perundang-Undangan Perkawinan, (Jakarta: DEPAG RI, 2009), h. 509-511. Vol. 10, No. 2, Oktober 2019 ISSN: 1978 - 1768
} 
proses cerainya masih dalam proses persidangan di Pengadilan Agama kemudian pihak kelurahan membuatkan statusnya sebagai jejaka/perawan.

Dalam pelaksanaannya berdasarkan putusan Pengadilan Agama Depok yang menjelaskan bahwa pernikahan yang dilakukan oleh tergugat 1 dan tergugat 2 setelah dikeluarkan akta nikah No. 10/9/46/2006 pada tanggal 4 Mei 2006 telah terjadi kesalahan terhadap status perkawinan tergugat 2 dan dinyatakan tidak memiliki kekuatan hukum.

Dalam hal ini, tergugat 2 masih berstatus istri orang lain. Hal tersebut tentulah menyalahi aturan yang tertuang dalam Undang-Undang No.1 tahun 1974 pasal 9, yaitu: "seorang yang masih terikat tali perkawinan dengan orang lain tidak dapat kawin lagi, kecuali dalam hal yang tersebut pada pasal 3 ayat (2) dan pasal 4 undang-undang ini".

Berdasarkan saksi-saksi yang hadir dalam persidangan yaitu ibu kandung dari tergugat 2 yang menyatakan bahwa tergugat 2 memang telah sengaja mengaku perawan dengan alasan suami terdahulunya mempersulit perkawinan antara tergugat 1 dan tergugat 2. Dan mengatakan bahwa secara hukum Islam sudah bercerai dan proses perceraiannya masih berjalan di Pengadilan Agama Depok.

Meskipun secara hukum Islam perceraian antara tergugat 2 dengan suami lamanya itu adalah sah namun menurut hukum yang berlaku di Indonesia itu tetaplah tidak memiliki kekuatan hukum, karena dalam hal ini yang berwenang memutuskan seseorang itu telah bercerai atau belum adalah Pengadilan. Sebagaimana dijelaskan dalam UU No.7 tahun 1989 jo. UU No.3 tahun 2006 pasal 65 ayat (1) yang berbunyi: "perceraian hanya dapat dilakukan di depan sidang Pengadilan setelah pengadilan yang bersangkutan berusaha dan tidak berhasil mendamaikan kedua belah pihak”.22 22 Mahkamah Agung RI, Undang-Undang Republik Indonesia No 3 Tahun2006 Tentang Perubahan Atas Undag-Undang No.7 Tahun 1989 Tentang Peradilan Agama, Jakarta: Dirjen Badan Peradilan Agama, 2006. Berdasarkan hal di atas, tergugat 2 telah sengaja memalsukan identitasnya dalam hal status perkawinanya dengan suami lamanya kepada pihak KUA. Namun meskipun data yang diajukan itu sudah dipalsukan, seharusnya pihak KUA tidak hanya menerima data-data yang diserahkan dari pihak Kelurahan untuk diteliti. Jika dilihat dari tempat tinggal tergugat yang masuk wilayah wewenang KUA Kecamatan Cimanggis, yang sudah barang tentu pihak KUA 
memiliki data-data tergugat 2 ketika melangsungkan pernikahan dengan suami pertamanya. Seperti yang dijelaskan di dalam pasal 26 Peraturan Menteri Agama No. 11 tahun 2007 Tentang Pencatatan Nikah, yaitu:

1. PPN mencatat pristiwa nikah dalam akta nikah

2. Akta nikah ditanda tangani oleh suami, isteri wali nikah, saksi-saksi dan PPN

3. Akta nikah dibuat rangkap 2 (dua), masing-masing disimpan di KUA setempat dan pengadilan.

4. Setiap pristiwa pernikahan dilaporkan ke kantor administrasi kependudukan di wilayah tempat pelaksanaan akad nikah ${ }^{9}$.

Di samping itu, di dalam PMA No.3 tahun 1975 pasal 52 ayat (2) dijelaskan bahwa: "Kepala Pegawai Pencatat Nikah pada tiap-tiap tiga bulan sekali wajib memeriksa daftar pemeriksaan nikah, akta nikah, buku pendaftaran talak, buku pendaftaran rujuk serta surat-surat yang bersangkutan dengan itu dari pegawai pencatat nikah yang ada dalam daerahnya."

Berdasarkan hal di atas, setiap calon pengantin ketika mengajukan kehendaknya untuk melangsungkan pernikahan amatlah sulit untuk memalsukan status perkawinan. Akan tetapi, berdasarkan PMA No.11 pasal 26 dan PMA No. 3 tahun 1975 pasal 52 ayat (2)yang seharusnya pihak KUA tidak dapat melangsungkan pernikahan karena telah memiliki data-data tergugat 2 pada saat melangsungkan pernikahan dengan suaminya yang pertama dengan cara mengkroscek ulang data-data tersebut.

Seharusnya pihak KUA/PPN dalam memeriksa data calon pengantin tidak hanya berhenti sampai disitu, akan tetapi, PPN berusaha untuk mendatangi tempat kediaman calon pengantin untuk memeriksa lebih lanjut tentang status pernikahan ataupun identitas calon pengantin dengan menanyakan kepada tetangga terdekat ataupun orang-orang yang mengenal calon pengantin tersebut, agar data yang diperiksa lebih akurat dan tidak akan terjadi kesalahan seperti pernikahan yang dilakukan ini. Karena bisa saja data yang masuk dari kelurahan itu telah dimanipulasi oleh yang bersangkutan.

Di samping itu, jika pemeriksaan yang dilakukan tanpa mengkroscek ulang data-data yang lama berdasarkan PMA No. 3 tahun 1975 pasal 52 ayat (2)

\footnotetext{
${ }^{9}$ Dirjen Bimas Islam, Himpunan Peraturan Perundang-Undangan Perkawinan, h. 435
} 
dikhawatirkan calon istri masih dalam masa iddah, karena jika isteri masih berada dalam masa iddah, maka calon suami masih memiliki hak untuk rujuk kembali, karena di dalam masa iddah suami masih berkewajiban memberikan nafkah dan tempat tinggal untuk mantan istri.

Berdasarkan hal di atas, seharusnya pihak KUA diberikan sanksi hukum karena telah lalai dalam tugasnya, namun menurut Drs. Abd. Hasan salah seorang penghulu di KUA Kecamatan Cimaggis Depok, ia berpendapat bahwa pihak KUA tidak dapat disalahkan karena ketidaktahuan apabila telah terjadi kesalahan dalam pernikahan yang dilangsungkan, dan apabila diketahui kalau pernikahan tersebut telah menyalahi aturan maka, pernikahan itu tidak akan dilangsungkan.

Namun jika demikian, maka dikhawatirkan akan timbul pernikahan seperti ini lagi. Jika PPN yang lalai dalam tugasnya mendapatkan sanksi hukum atas pelanggaran tersebut maka nantinya PPN dalam memeriksa data-data calon pengantin akan hati-hati dan teliti dalam memeriksanya, sehingga tidak akan terjadi lagi pernikahan yang menyalahi peraturan undang-undang perkawinan.

Adapun sanksi yang dikenakan adalah sanksi pidana atas pelanggaran jabatan yang tertuang di dalam KUHP pasal 557 ayat (1), yang berbunyi: "Diancam dengan pidana denda paling banyak seribu lima ratus rupiah, seorang pegawai negeri Catatan Sipil yang bertindak berlawanan dengan ketentuan aturan-aturan umum mengenai register atau akta catatan sipil, mengenai tata cara sebelumnya perkawinan atau pelaksanaan perkawinan"

Berdasarkan pasal di atas denda yang dikenakan sudahlah sangat tidak relevan jika diterapkan pada zaman sekarang, kemungkinan denda seribu lima ratus rupiah sama dengan satu juta lima ratus ribu rupiah. Oleh karena itu, penulis berpendapat, bahwa pihak KUA/PPN yang bertugas menangani hal itu kurang teliti dalam melaksanakan tugasnya, yaitu dalam memeriksa dan meneliti data-data calon pengantin, sehingga menimbulkan permasalahan tersebut yang mengakibatkan batalnya perkawinan antara tergugat 1 dan tergugat 2. Hal ini disebabkan karena proses perceraian antara tergugat 2 dan suami pertamanya masih berjalan di Pengadilan Agama Depok dan tergugat 2 secara hukum masih berstatus isteri orang lain. Dan agar

\footnotetext{
${ }^{10}$ Andi Hamzah, KUHP dan KUHAP, cet. Ke-13, (jakarta: PT. Rineka Cipta, 2006), h.219.
} 
tidak terjadi lagi perkawinan seperti ini, maka PPN yang bertugas dapat dikenakan sanksi pidana atas pelanggaran tersebut

\section{PENUTUP}

Adapun cara Pegawai Pencatat Nikah meneliti data-data calon pengantin adalah dengan meneliti dan memeriksa data-data berdasarkan surat-surat yang diterima dari Kelurahan. Dan pada dasarnya pihak KUA menerima berkas yang sudah diselesaikan dari pihak Kelurahan. Namun seharusnya pihak KUA tidak hanya memeriksa dan meneliti data yang masuk dari kelurahan tetapi mengkroscek ulang data-data lain yang ada di KUA atau salah satu pihak KUA mendatangi tempat kediaman calon istri dengan cara menanyakan kepada tetangga ataupun orang-orang yang mengenal calon pengantin tersebut. Agar dalam pelaksanaan perkawinan tidak terjadi penyimpangan terhadap identitas maupun status perkawinan. Adapun penyelesaian pernikahan yang salah satu pihaknya terikat perkawinan adalah dengan mengajukan pembatalan perkawinan ke Pengadilan Agama oleh pihak-pihak yang merasa dirugikan atau pihak KUA yang menangani pernikahan itu ketika mengetahui terdapat masalah dalam pernikahan itu. Sesuai dengan pasal 23 UU No.1 tahun 1974 tentang Perkawinan jo. Pasal 73 Kompilasi Hukum Islam.

\section{DAFTAR PUSTAKA}

Abbas, Ahmad Sudirman, Pengantar Pernikahan, cet. I, Jakarta: Prima Heza Lestari, 2006.

Abdurrahman, Kompilasi Hukum Islam di Indonesia, Jakarta: Akademika Pressindo, 2007.

Al-Damsyiqy, Taqiyyudin Abu Bakar Ibn Muhammad, Kifayatul Akhyar Fi Hilli Ghoyatil Ikhtishor, Juz II, Semarang: Maktabah Toha Putra, t.t.

Ali, Zainudin, Hukum Perkawinan Islam di Indonesia, Jakarta: Sinar Grafika, 2006.

Al-Jawi, Muhammad Shiddiq. artikel diakses pada 16 April 2010 dari http://www.khilafah1924.org/index.php?option=com_content\&task=view\&id $=337 \&$ Itemid $=3$.

Al-Jaziri, Abd. ar-Rahman, al-Fiqh 'Ala al-Mazzahib al-Arba'ah, cet. Ke-1, Beirut: Dar al-Fikr, 2002

Al-Khatib, Muhammad al-Syarbini, Mughnil Muhtaj Bab II, Jilid VII, Mesir: Mustafa Babil Halabi. 
Al-Syuti, Jalaluddin Abdurrahman Ibn Abu Bakar, Jami'u al-Shogir Fi al-Ahadits Basyiran Nazir, Kairo: Dar al-Katib, 1967

Al-Zuhaili, Wahbah, Al-Fiqh Al-Islami Wa Adillatuhu, cet. Ke-3, Beirut: Dar Al-Fikr, 1989.

Amir, Syarifudin, Hukum Perkawinan Islam di Indonesia, Jakarta: Kencana Prenada Media Group, 2006.

An-Nabhani, Syaikh Taqiyuddin, an-Nizham al-Ijtima’i Fi al-Islam, Beirut : Darul Ummah, 2003. 